\title{
Shadow of domestic violence and extramarital sex cohesive with spousal communication among males in Nepal
}

\author{
Dharma Nand Bhatta
}

\begin{abstract}
Background: Public health and human right issues are challenging in low and middle income countries. The main objectives of this paper were to determine the prevalence and factors associated with domestic violence, extramarital sex, and spousal communication among male.

Methods: A cross-sectional study among 2466 married males in Kathmandu, Nepal was conducted using random sampling method. Adjusted odds ratios (AORs) and 95\% confidence intervals (Cl) of associated factors were estimated by stepwise backward likelihood ratio method.

Results: Prevalence of domestic violence was $63.14 \%$ (95\% Cl 61.20-65.05), extramarital sex was $32.12 \%$ (95\% Cl 30.27-34.00), and spousal communication was $48.87 \%$ (95\% Cl 46.85-50.90). Nearly one in five male (18.20\%) had not used condom during extramarital sex.

Interestingly, male who had more than three or equal children were less likely to have perpetrated domestic violence compared with those who had less children. Older male aged 25 and above were more likely (AORs $=1.55$, 95\% Cl 1.19-2.03) to have extramarital sex compared with male aged 24 or below. Those male who had studied secondary or higher level of education were less likely to have extramarital sex compared to those who had primary level or no education. Male who had higher income were more likely to have spousal communication compared to those who had less income. Surprisingly, those male who had extramarital sex were less likely to have spousal communication compared with those was not involved in extramarital sex.

Conclusion: Practice of domestic violence and extramarital sex is quite common among married male in Nepal, where spousal communication is sparse. These findings can be used to advocate for immediate attention and activities needs to be endorsed by policymakers and programmers.
\end{abstract}

Keywords: Violence, extramarital sex, Contraceptive, Spousal communication, Nepal

\section{Background}

Globally violence against women is a grave fact which hacks every social and economic class families. According to World Health Organization (WHO), 10-69\% of women experienced with physically beaten by husband at several point in their lives [1]. Psychological and sexual violence is greatly common in the world, which has great public health impacts [1-3], viz. HIV, alcohol abuse and drug addiction, homicide and suicides, mental disorders, miscarriages, preterm labor, fetal distress and low

Correspondence: dnbhatta@yahoo.com

Department of Public Health, Pokhara University, Nobel College, Sinamangal, Kathmandu, Nepal birth weight infants [4-6]. Globally more than fifty population based studies revealed that around $10-50 \%$ of women reported having been physically assaulted by male partner [7]. Similarly, study conducted by WHO reported that $13-61 \%$ of women had experienced physical violence and $10-50 \%$ of women informed being sexually abused [8]. Study from India showed that $24 \%$ being kicked, $12 \%$ were threatened by their husbands [9]. Study from Bangladesh revealed that $67 \%$ of women accounted experiencing domestic violence [6]. Likewise, a study conducted in Nepal reported $46.2 \%$ of women reported experiencing sexual violence [10]. Albeit the degree of indication has been mounting worldwide and 
studies in Nepal to assess the prevalence of violence in different settings and populations is sparse. A higher percentage of married accounted experiencing violence contrasted to unmarried [11]. WHO reported that unnatural sex by male partners ranged from $4 \%$ in Serbia and Montenegro to $46 \%$ in Bangladesh and Ethiopia [12].

Domestic violence has strong association with low income, low education level of husband, alcohol and drug use, young age, and eye witnessing DV during childhood, HIV status, polygamy, multiple sexual partners, use of contraceptives, woman's power over resources, woman's education, employment and culture [13-24]. Intimate partner violence is strongly connected with male patriarchal principles [25]. Patriarchal family, culture, society and religious principles in Nepal enforce the violence [26]. Though, government of Nepal passed a law on genderbased violence which made punishment range from a fine or six months in jail or both depending on the type of violence, however this law is seldom imposed strictly [27,28].

Both married men and women have reported the practice of extramarital sexual and more frequent among men. Study from Nigeria revealed that the $79 \%$ of transport workers, $46 \%$ of army, $61 \%$ of policeman had engaged in extramarital sex and demographic and health survey showed that $11 \%$ of married men reported having had extramarital sex $[29,30]$. Men with more than one wives are more likely to have extramarital sex and always at risk of extramarital sex [30]. It has been established in many countries that HIV is transmitted typically throughout sexual behaviors [31]. Previous studies from other countries have highlighted the risk of men infecting their wives after extramarital sex during periods of separation and the continuing impact of the epidemic is expected to be determined by men who have extramarital sex $[32,33]$.

Fertility indicators have been influenced by changes in marital relationships [34,35]. Spousal communication has concern primarily husbands' and wives' discrepancy information of communication on fertility and family planning [36-38]. Limitations of the various studies cannot make causal inferences whether communication leads contraceptive use or not $[39,40]$. Various factors play an important role in husband wife relationship including vivid social, economic and institutional changes and cultural shift [41]. Spousal communication is the vital factor which helps to change the attitude and intention of the people in the use of contraceptives. Studies from Africa observe immense agreement highlighting on spousal communication and contraceptive use [36,39]. Those researches have repeatedly recommended that women play the crucial role in making contraceptive choices [42]. Ignored role of men's in contraceptive manners might be warning the achievement of family planning (FP) [40].
The main objective is to determine the prevalence and factors associated with domestic violence, extramarital sex and spousal communication. Culturally vibrant and patriarchic societies of Nepal with low socio-economic, decision-making abilities of women and beliefs have immense impact on women's health [43]. Urgent needs to address these factors which help to improve women's health.

\section{Materials and methods \\ Design and settings}

A cross-sectional study was carried out in different twenty three village development committees (VDCs) and one municipality of Kathmandu district which is the central part of Nepal. Study was conducted from May to December 2010. A married male of a household head and interest to participate in the study were the inclusion criteria.

\section{Sampling and sample}

Two-staged random sampling technique was applied in order to sample the married males. The first stage of sampling included random selection of 23 VDCs and one municipality in Kathmandu. In order to select these 23 VDCs and one municipality, a list of all the VDCs and municipalities those located in Kathmandu was obtained from the office of the District Development Committee in Kathmandu. This list included all the wards of VDCs and municipalities. In the second stage, one ward was selected randomly from each sampled VDCs and municipality. Households from these wards were not differentiated by subject and had taken in the same geographical area. The number of married males of household heads in each wards ranged from 200 to 400 households. To reach sampled household heads in 23 wards of VDCs and one ward of municipality, 100 household heads from each VDC and 200 household heads from municipality were taken for interview as a sample. Among the total 2500 household heads, 34 were refused to take participation in the study. Hence the total sample size was estimated to be 2466 male.

\section{Data collection and measures}

Structured questionnaires were used for the data collection and included questions on socio-demographic characteristics of the respondent, along with his practice of domestic violence, extramarital sex and spousal communication. Pre-testing of the questionnaires with married male in non-sampled areas was carried out and the necessary changes in the questionnaire were incorporated.

The questionnaires were drafted in English and translated into Nepali, Nepal's most common language. All the changes were methodically checked to ensure that meaning of the original English version was maintained. Researchers were trained with regards to ethical thoughts 
while conducting research on sensitive issues [43]. Participants involved in the study were fully informed about the nature of the study, objectives, and confidentiality of the data. Each participant's verbal consent was obtained after assuring confidentiality. The face-to-face interview was conducted in a secret place without the presence of third person. The researcher did not give any financial recompense to the interviewed male. Confidentiality of information was guaranteed by removing individual identifiers from the fulfilled questionnaires, which sheltered respondents against unpleasant impacts from participating in the study. The institutional ethical review committee has approved this study.

Domestic violence perpetrated by a male is used as the dependent variable in this study. Respondents were asked three questions:

i. Have you ever been practiced any one of these activities (slapped, or pushed, or kicked, or beaten, or choked) with your wife?

ii. Have you ever been forced your wife to have sexual intercourse?

iii. Have you ever been embarrassed your wife?

Those men who performed at least one of the three forms of violence were considered to have performed domestic violence by male. Domestic violence, extramarital sex and spousal communication also measured as a primary outcomes or dependent variable. With regard to extramarital sex, this measure was focused on whether they had had sex even once before ever with other than wife. Similarly, the question on extramarital sex was dichotomized into yes and no. Likewise, spousal communication variable was based on the history of discussion with their wife regarding fertility, and FP which was then dichotomized into yes and no. Rest of the questions related on contraceptive use was also coded as yes and no. Contraceptive used by males and male decision maker for contraceptive uses were considered as secondary measures.

\section{Data analysis}

The coded data was entered into SPSS version 16 for further processing and analysis. Bivariate and multivariate techniques were applied to identify the factors associated with the likelihood of practicing domestic violence, extramarital sex, and spousal communication. Researcher used the Hosmer and Lemeshow test to assess goodness of fit of the models and the likelihood ratio test to assess relative contribution of terms entered into the model. The variables were also examined in the multivariate analysis in order to identify the significant predictors after controlling for other variables. Logistic regression results were presented as both crude and adjusted odds ratios (AORs) with 95\% confidence intervals. In the bivariate and multivariate analyses, $\mathrm{p}$-value of less than or equal to 0.05 was considered to be significant. The data was cleaned and cross-checked daily before and after data entry for completeness and accuracy.

\section{Results}

The respondents mean age \pm SD was $32.4 \pm(8.9)$ years, where a large majority of the respondents $(81.38 \%, 95 \%$ CI $79.80-82.90)$ were aged 25 years and above. Out of total respondents, $72.26 \%$ (95\% CI 70.45-74.02) of the male had secondary or higher level education, $48.91 \%$ (95\% CI 46.91-50.90) of the male had formal employment, $88.32 \%$ (95\% CI 86.99-89.56) of the male followed Hindu religion, and $82.48 \%$ (95\% CI $80.92-83.96$ ) of the male were from non-indigenous ethnicities. Majority of the respondents (67.77\%, 95\% CI 66.76-69.73) had less than or equal two children, whereas $16.67 \%$ (95\% CI 15.21-18.20) of the male had desire for more children (Table 1).

A large majority of the respondent (81.82\%) had used condom during extramarital sex. Among the 1710 respondents, male said that the reasons for not to use FP method were: the feeling that this is a woman's duty (15.81\%), it reduced sexual power $(23.20 \%)$, it reduced working power $(32.12 \%)$, had cultural and religious barriers $(15.31 \%)$, and had other causes $(13.71 \%)$ (Table not shown).

Table 2 shows the indication of male influences in different issues. Regarding decision making for family planning, two third of the respondent $(66.16 \%, 95 \% \mathrm{CI}$ 64.23-68.06) indicated that they were decision makers for FP. Large majority of the wives $(92.10 \%, 95 \%$ CI 90.95-93.15) needed approval or consent to use contraceptives. This is in spite of the claimed by most of the respondents that they discussed about family planning issues. Overall, half of the male $(48.87 \%$, 95\% CI $46.85-$ 50.90) indicated that they had spousal communication regarding fertility, and FP. Overall, nearly two third of the male $(63.14 \%, 95 \%$ CI $61.20-65.05)$ reported that they had perpetrated domestic violence with their wives. One third of the respondents $(32.12 \%, 95 \%$ CI 30.27 34.00) reported that they had extramarital sexual relation. Underreporting of such sexual activities was highly possible due to the sensitive nature of the study.

Those male who had more than three or equal children were less likely to have perpetrated domestic violence compared with those who had less than two or equal children. Male aged 25 and above (AORs $=1.59$, 95\% CI 1.182.16), had education level secondary or higher (AORs = 1.68, 95\% CI 1.35-2.09), had income 5001 NPR or above per month (AORs $=1.78,95 \%$ CI 1.42-2.21), had formal employment $(\mathrm{AORs}=1.68,95 \%$ CI 1.34-2.09) and were non-indigenous ethnicities $(\mathrm{AORs}=1.70,95 \% \mathrm{CI}$ 
Table 1 Socio-demographic information $(\mathrm{N}=2466)$

\begin{tabular}{|c|c|c|}
\hline Characteristic & $\begin{array}{l}\text { Frequencies } \\
\text { (Percentage) }\end{array}$ & $95 \% \mathrm{Cl}$ \\
\hline${ }^{* *}$ Age & $32.4 \pm(8.9)$ & - \\
\hline 25 years and above & 2007 (81.38) & $79.80-82.90$ \\
\hline 24 years and young & 459 (18.62) & $17.09-20.21$ \\
\hline \multicolumn{3}{|l|}{ Income level Monthly (NPR)* } \\
\hline 5001.00 NPR or above & $1188(48.17)$ & $46.18-50.16$ \\
\hline 5000.00 NPR or below & $1278(51.83)$ & $49.83-53.81$ \\
\hline \multicolumn{3}{|l|}{ Education level } \\
\hline Secondary or Higher Level & $1782(72.26)$ & $70.45-74.02$ \\
\hline Uneducated or Primary Level & $684(27.74)$ & $25.97-29.55$ \\
\hline \multicolumn{3}{|l|}{ Occupation } \\
\hline Formal employment & $1206(48.91)$ & $46.91-50.90$ \\
\hline Informal or no employment & $1260(51.09)$ & $49.09-53.09$ \\
\hline \multicolumn{3}{|l|}{ Religion } \\
\hline Hindu & $2178(88.32)$ & 86.99. - 89.56 \\
\hline Non-Hindu & $288(11.68)$ & $10.44-13.01$ \\
\hline \multicolumn{3}{|l|}{ Ethnicity } \\
\hline Non-Indigenous & $2034(82.48)$ & $80.92-83.96$ \\
\hline Indigenous & $432(17.52)$ & $16.04-19.08$ \\
\hline${ }^{* *}$ No. of Children $(\mathrm{N}=2178)$ & $2.17 \pm(1.09)$ & - \\
\hline$\leq 2$ Children & $1476(67.77)$ & $66.76-69.73$ \\
\hline$\geq 3$ Children & $702(32.23)$ & $30.27-34.24$ \\
\hline Desire more children & $441(16.67)$ & $15.21-18.20$ \\
\hline
\end{tabular}

${ }^{* 1}$ U.S. $\$=85.00 \mathrm{NPR}{ }^{*}$ Mean \pm standard deviation $\mathrm{Cl}=$ Confidence Interval.

1.30-2.23) have more likely to have perpetrated domestic violence (Table 3).

Findings regarding extramarital sexual relation revealed that the older male aged 25 and above (AORs $=1.55,95 \%$ CI 1.19-2.03), had income 5001 NPR ( 1 USD $=90$ NPR)

Table 2 Male influence on different issues ( $N=2394$ )

\begin{tabular}{|c|c|c|}
\hline Characteristic & $\begin{array}{l}\text { Frequencies } \\
\text { (Percentage) }\end{array}$ & $95 \% \mathrm{Cl}$ \\
\hline Family planning method used by men & $684(28.57)$ & $26.76-30.43$ \\
\hline $\begin{array}{l}\text { Men decision maker for contraceptive } \\
\text { use }\end{array}$ & $1584(66.16)$ & $64.23-68.06$ \\
\hline Nife decision maker to use contraceptive & $90(03.76)$ & $03.03-04.60$ \\
\hline $\begin{array}{l}\text { Wife needed approval to use } \\
\text { contraceptive }\end{array}$ & $2205(92.10)$ & $90.95-93.15$ \\
\hline $\begin{array}{l}\text { Spousal communication regarding family } \\
\text { planning }\end{array}$ & $1170(48.87)$ & $46.85-50.90$ \\
\hline Family planning clinic visit with wives & $261(10.90)$ & $09.68-12.22$ \\
\hline $\begin{array}{l}\text { Discussion with wives regarding HIV and } \\
\text { AIDS }(N=2466)\end{array}$ & $972(39.42)$ & $37.47-41.38$ \\
\hline Extramarital sexual relation & $792(32.12)$ & $30.27-34.00$ \\
\hline Men attempt domestic violence & $1557(63.14)$ & $61.20-65.05$ \\
\hline
\end{tabular}

Table 3 Associated factors for domestic violence ( $N=2466)$

\begin{tabular}{|c|c|c|}
\hline Characteristic & $\begin{array}{c}\text { Crude odds } \\
\text { ratios with } \\
95 \% \text { confidence } \\
\text { interval }\end{array}$ & $\begin{array}{l}\text { Adjusted odds } \\
\text { ratios with } \\
95 \% \text { confidence } \\
\text { interval }\end{array}$ \\
\hline Age above 25 years & $1.09(.88-1.34)$ & $1.59(1.18-2.16)^{* * d}$ \\
\hline \multicolumn{3}{|l|}{ Age 24 years \& below -Ref } \\
\hline Education secondary or higher & $2.33(1.90-2.84)^{*}$ & $1.68(1.35-2.09)^{* c}$ \\
\hline \multicolumn{3}{|l|}{ Uneducated or primary level- Ref } \\
\hline Income 5001 NPR or above & $2.19(1.85-2.59)^{*}$ & $1.78(1.42-2.21)^{* d}$ \\
\hline \multicolumn{3}{|l|}{5000 NPR or less/month- Ref } \\
\hline Formal employment & $2.23(1.89-2.64)^{*}$ & $1.68(1.34-2.09)^{* d}$ \\
\hline \multicolumn{3}{|l|}{ Informal or no employment - Ref } \\
\hline Non-Indigenous ethnicity & $2.23(1.75-2.83)^{*}$ & $1.70(1.30-2.23)^{* d}$ \\
\hline \multicolumn{3}{|l|}{ Indigenous ethnicity - Ref } \\
\hline$\geq 3$ Children & $.54(.44-.67)^{*}$ & $.60(.48-.75)^{* d}$ \\
\hline$\leq 2$ Children - Ref & & \\
\hline
\end{tabular}

or above per month (AORs $=1.24$, 95\% CI 1.02-1.49), and had more than three or equal children (AORs $=1.97$, 95\% CI 1.59-2.45) were more likely to have extramarital sex compared with male aged 24 or below, had income 5000 NPR or below, and had less than two or equal children. However, those male who had studied secondary or higher level of education and had desire for more children were less likely to have extramarital sex compared with those who had primary level or no education and had no more desire for children (Table 4).

Table 5 indicates the factors associated with spousal communication. The analysis found that male who had desire for more children were three times $(\mathrm{AORs}=3.00$, 95\% CI 2.32-3.90) more likely to have spousal communication compared to those who had no more desire for children. Male with more than three or equal children (AORs $=1.30,95 \%$ CI 1.04-1.61), and income 5001 NPR or above per month (AORs $=1.22,95 \%$ CI $0.98-1.52)$ were more likely to have spousal communication compared to those who had less than two or equal children, and had income 5000 NPR or below. Unexpectedly, those male who had studied secondary or higher level of education, and had extramarital sex were less likely to have spousal communication compared with those who had primary level or no education and were not involved in extramarital sex.

Those male who had studied secondary or higher level of education were five times $(\mathrm{AORs}=5.14,95 \%$ CI 2.57 10.27) more likely to have their wives needed approval to use contraceptive compared with those who had primary level or no education. Those male who believed in Hindu religion were about three times $(\mathrm{AORs}=2.50$, 
Table 4 Associated factors for extramarital sex $(\mathrm{N}=2466)$

\begin{tabular}{|c|c|c|}
\hline Characteristic & $\begin{array}{l}\text { Crude odds } \\
\text { ratios with } \\
95 \% \text { confidence } \\
\text { interval }\end{array}$ & $\begin{array}{l}\text { Adjusted odds } \\
\text { ratios with } \\
95 \% \text { confidence } \\
\text { interval }\end{array}$ \\
\hline Age above 25 years & $1.99(1.62-2.46)^{*}$ & $1.55(1.19-2.03)^{* a}$ \\
\hline \multicolumn{3}{|l|}{ Age 24 years \& below -Ref } \\
\hline Education secondary or higher & $.62(.51-.76)^{*}$ & $.77(.62-.95)^{* * a}$ \\
\hline \multicolumn{3}{|l|}{ Uneducated or primary level- Ref } \\
\hline Desire more children & $.29(.24-.36)^{*}$ & $.34(.27-.43)^{* a}$ \\
\hline \multicolumn{3}{|l|}{ No more desire - Ref } \\
\hline Income 5001 NPR or above & $1.26(1.06-1.49)^{* *}$ & $1.24(1.02-1.49)^{* * \mathrm{~b}}$ \\
\hline \multicolumn{3}{|l|}{5000 NPR or less/month- Ref } \\
\hline Non-Indigenous ethnicity & $1.49(1.20-1.85)^{*}$ & $1.42(1.13-1.78)^{* * b}$ \\
\hline \multicolumn{3}{|l|}{ Indigenous ethnicity - Ref } \\
\hline$\geq 3$ Children & $1.91(1.55-2.35)^{*}$ & $1.97(1.59-2.45)^{* b}$ \\
\hline$\leq 2$ Children - Ref & & \\
\hline
\end{tabular}

95\% CI 1.12-5.71) more likely to have their wives needed approval to use contraceptive compared to those who believed in other than Hindu religion. However, those male who had more than three or equal children and had desire for more children were less likely to have their wives needed approval to use contraceptive compared with those who had less than two or equal children and had no more desire for children.

Table 6 shows the factors associated with FP methods used by men. Education, age, income, desire for more children, attempted domestic violence and the number of surviving children were found to have a significant impact on contraceptive use. Furthermore, the variables age, level of education, religion and ethnicity had statistical significant effect on decision making for contraceptive use. Unexpectedly, those male who had studied secondary or higher level of education were four times (AORs $=4.11,95 \%$ CI 3.12-5.42) more likely to have decision makers for contraceptive use compared with those who had primary level or no education. Interestingly, those male who had attempted domestic violence were less likely to have decision makers compared with those who did not have such activities.

\section{Discussion}

The results of the study indicated that prevalence of domestic violence is high. The finding is similar with previous studies from different countries [1,7-12]. Extramarital sex is unacceptable in Nepalese society and the results indicated that one third of the men have extramarital sexual relations. A study from Cameroon has
Table 5 Associated factor for spousal communication ( $\mathrm{N}=\mathbf{2 3 9 4 )}$

\begin{tabular}{|c|c|c|}
\hline Characteristic & $\begin{array}{c}\text { Crude odds } \\
\text { ratios with } \\
95 \% \text { confidence } \\
\text { interval }\end{array}$ & $\begin{array}{c}\text { Adjusted odds } \\
\text { ratios with } \\
95 \% \text { confidence } \\
\text { interval } \\
\end{array}$ \\
\hline Income 5001 NPR or above & $.60(.51-.70)^{*}$ & $1.22(.98-1.52)^{c}$ \\
\hline \multicolumn{3}{|l|}{5000 NPR or less/month- Ref } \\
\hline Education secondary or higher & $.28(.23-.34)^{*}$ & $.33(.26-.41)^{* c}$ \\
\hline \multicolumn{3}{|l|}{ Uneducated or Primary level- Ref } \\
\hline Formal employment & $.36(.31-.43)^{*}$ & $.65(.52-.82)^{* c}$ \\
\hline \multicolumn{3}{|l|}{ Informal or no employment - Ref } \\
\hline Hindu religion & $.27(.20-.36)^{*}$ & $.50(.35-.72)^{* c}$ \\
\hline \multicolumn{3}{|l|}{ Non-Hindu - Ref } \\
\hline Non-Indigenous ethnicity & $.35(.27-.44)^{*}$ & $.75(.56-1.02)^{c}$ \\
\hline \multicolumn{3}{|l|}{ Indigenous ethnicity - Ref } \\
\hline$\geq 3$ Children & $1.32(1.09-1.59)^{* *}$ & $1.30(1.04-1.61)^{* * c}$ \\
\hline \multicolumn{3}{|l|}{$\leq 2$ Children - Ref } \\
\hline Desire more children & $2.67(2.13-3.34)^{*}$ & $3.00(2.32-3.90)^{* c}$ \\
\hline \multicolumn{3}{|l|}{ No more desire - Ref } \\
\hline Extramarital sexual relation & $1.00(.84-1.19)$ & $.79(.64-.97)^{* * c}$ \\
\hline
\end{tabular}

No relation - Ref

Associated factors for wife's approval to use contraceptive ( $\mathrm{N}=2394)$

Age above 25 years

$2.37(1.44-3.90)^{*} \quad 4.47(2.21-9.03)^{* a}$

Age 24 years \& below -Ref

Income 5001 NPR or above $\quad 1.72(1.27-2.33)^{*} \quad 1.52(1.12-2.07)^{* * b}$

5000 NPR or less/month- Ref

Education secondary or higher $7.53(3.83-14.80)^{*} \quad 5.14(2.57-10.27)^{* a}$

Uneducated or Primary level- Ref

Hindu religion $\quad 2.79(1.41-5.52)^{* *} \quad 2.5(1.12-5.71)^{* * a}$

Non-Hindu - Ref

Non-Indigenous ethnicity $\quad 1.28(.84-1.95) \quad .51(.30-.87)^{* * a}$

Indigenous ethnicity - Ref

$\geq 3$ Children

$.13(.07-.26)^{*} \quad .14(.07-.27)^{* a}$

$\leq 2$ Children - Ref

Desire more children

$.80(.52-1.22) \quad .67(.42-1.06)^{\mathrm{a}}$

No more desire - Ref

${ }^{*} \mathrm{P}<0.001,{ }^{* * P}<0.05$.

${ }^{\mathrm{b}}$ Adjusted with age, income, religion.

${ }^{a}$ Adjusted with age, education, religion, desire of children, ethnicity, no. of children.

'Adjusted with income, education, employment, religion, ethnicity, desire of children, extra marital sexual relation, no. of children.

revealed similar result [44] However, a study from Nigeria found higher rate of extramarital sexual relations $[29,30]$. Spousal communication might help to establish harmony among family relationship and result from this study indicated low level of spousal communication about family planning. This finding is similar 
Table 6 Associated factors for FP method use $(N=2394)$

\begin{tabular}{|c|c|c|}
\hline Characteristic & $\begin{array}{l}\text { Crude odds } \\
\text { ratios with } \\
95 \% \text { confidence } \\
\text { interval }\end{array}$ & $\begin{array}{c}\text { Adjusted odds } \\
\text { ratios with } \\
95 \% \text { confidence } \\
\text { interval }\end{array}$ \\
\hline Age above 25 years & $1.65(1.33-2.04)^{*}$ & $.74(.54-1.02)$ \\
\hline \multicolumn{3}{|l|}{ Age 24 years \& below -Ref } \\
\hline Income 5001 NPR or above & $.85(.71-1.00)$ & $1.30(1.04-1.62)^{* *}$ \\
\hline \multicolumn{3}{|l|}{5000 NPR or less/month- Ref } \\
\hline Education secondary or higher & $.35(.27-.44)^{*}$ & $.41(.31-.55)^{*}$ \\
\hline \multicolumn{3}{|l|}{ Uneducated or Primary level- Ref } \\
\hline Hindu religion & $.15(.09-.24)^{*}$ & $.09(.05-.18)^{*}$ \\
\hline \multicolumn{3}{|l|}{ Non-Hindu - Ref } \\
\hline$\geq 3$ Children & $2.48(1.93-3.19)^{*}$ & $2.05(1.56-2.71)^{*}$ \\
\hline \multicolumn{3}{|l|}{$\leq 2$ Children - Ref } \\
\hline Desire more children & $.78(.62-.99)^{* *}$ & $.72(.55-.95)^{* *}$ \\
\hline \multicolumn{3}{|l|}{ No more desire - Ref } \\
\hline Men attempt domestic violence & $1.87(1.56-2.24)^{*}$ & $1.29(1.04-1.61)^{* *}$ \\
\hline Not attempt - Ref & & \\
\hline
\end{tabular}

Associated factors for male decision making to contraceptive use $(\mathrm{N}=\mathbf{2 3 9 4})$

Age above 25 years $1.63(1.30-2.05)^{*} \quad 1.57(1.15-2.14)^{* *}$

Age 24 years \& below -Ref

Income 5001 NPR or above

$1.09(.92-1.30) \quad .67(.54-.82)^{*}$

5000 NPR or less/month- Ref

Education secondary or higher

Uneducated or Primary level- Ref

Hindu religion

$2.32(1.70-3.16)^{*}$

$1.43(.95-2.16)$

Non-Hindu - Ref

Non-Indigenous ethnicity

$2.40(1.85-3.10)^{*} \quad 1.49(1.06-2.10)^{* *}$

Indigenous ethnicity - Ref

$\geq 3$ Children

$.67(.54-.82)^{*} \quad .70(.55-.88)^{* *}$

$\leq 2$ Children - Ref

Desire more children

$.64(.50-.82)^{*} \quad .66(.50-.87)^{* *}$

No more desire - Ref

Men attempt domestic violence

$.62(.52-.73)^{*}$

$.83(.68-1.02)$

Not attempt - Ref

${ }^{*} \mathrm{P}<0.001,{ }^{* * P}<0.05$.

with previous study from Nepal based on female respondents [39]. Older age, wealthier status and education were identified common associated factors with domestic violence, and extramarital sex.

The finding revealed that older age, educated, and wealthier status of men were strongly associated with DV. However previous studies result were contradictory that young age, low education and low income were associated with DV [13-19]. Study of review on marital rape and other study from India have also contradictory results with education and DV [45]. This result is contradictory with previous research suggesting that the pressures of poverty may put a major load on families and these anxieties can explode into violence [46]. Educated male might be traditional on their attitude and practice. Nepalese societies constructed with patriarchal family, have traditional culture, and religious principles might enforce DV [26]. Similarly the finding revealed that non-indigenous people has higher probability of DV. In Nepal non-indigenous people are more devoted in religious norms than indigenous people. Systematic review of prevalence on domestic violence from different countries also highlighted that no ethnic, tribal or socioeconomic group were protected by means of DV [47].

The finding indicated that educated men have less extramarital sexual relation. However previous studies from Cameroon and United States of America have contradictory findings with education status and extramarital sex $[44,48,49]$. Finding from this study showed that male having higher age and higher level of income was significantly associated with extramarital sex. Similar results from previous studies found that higher income and higher age were associated with extramarital sex $[44,48]$ In contrast other literature from Bangladesh found that prominent risk of extramarital sex among lowest income groups [50]. Marital disharmony might be increased in later stage of life which is the reason behind extramarital sex among older men than younger. Most of the male reported that reasons for engaged on extramarital sex were: feeling more enjoyment with other than wife, wife complaint pain during sex after second child birth, and marital unhappiness.

Positive association were found among higher level of education, and formal employment with spousal communication but was not found protective factors. This may be due to underlying socio-religious practices among Nepalese women who are more controlled to their conservative gender roles [43]. Education consistently has been shown to influence reproductive manners. In addition, married men who had extramarital sex were less likely to had spousal communication. Systematic review from developing counties highlighted that many women still needing their husbands' consent to use contraceptives [51]. Strong cultural, religious beliefs and conservative attitudes might be the reason for wife needed approval for contraceptive use in Nepal. Male who had conservative attitudes toward domestic violence were less likely to engage in decision making for contraceptive use. These findings are an agreement with earlier research [51]. Men who were willing to have more children were more likely to establish spousal communication. This might be the interest of men when he desires more children than he might start discussion to fulfill his desire from wife. 


\section{Strengths and weakness of the study}

The main strength was population based study that could represent from both rural and urban area. Second strength was adequate sample size for analysis, and sampling techniques for data collection. Reliability and validity were applied in each step and associated factors were set with the appropriate analytical technique.

This study provides the most comprehensive information, albeit, there are some potential limitations in the interpretation of the results for this study. First, because of the cross-sectional study design, the analysis can only offer evidence of statistical association, and cannot show cause-effect relationships. Second, in this study sample is married male, so results regarding the prevalence of domestic violence should not be generalized to all male in Nepal. Third, due to the sensitive nature of the issue, the prevalence of domestic violence and extramarital sex experience may have been underreported. However, the privacy settings adjacent the study and the excellent rapport that was built before the interview are expected to have reduced purposeful misreporting.

\section{Implications of findings}

Study finding provides strapping evidence of eminent prevalence and increased probability of domestic violence, extramarital sex and inadequate level of spousal communication which depicts attention to key issues. Finding highlighted the need for policy maker, healthcare workforce to recognize the amplified susceptibility of both men and women with psychological problems of domestic violence, vulnerability of sexually transmitted diseases and to be arranged to recognize and tackle these concerns in policy, programs and clinical plans. Clinical and legal systems must be strong and need to develop with collaborations that can address victims' needs and address long term or short term health impacts [52]. Qualitative and quantitative mixed method based research among both men and women need to indentify route cause of domestic violence and extramarital sex. Further intervention is needed to find out the effectively reducing vulnerability of domestic violence and extramarital sex and how to improve impact on health.

\section{Conclusion}

The findings demonstrated that domestic violence and extramarital sex is a significant public health problem in low income countries. Males are exposed to health hazard due to their risky sexual behavior, thus sex education and awareness should be provided and promoted. Interventions focusing improved spousal communication may help prevent violence and reduce involvement on extramarital sex. Equal and immediate attention needs to be endorsed by policymakers and programmers to address these public health issues.

\section{Competing interests}

The author declares no conflict of interest.

\section{Acknowledgements}

The author wish to thank the respondents for participating in the study. I would also like to thank Dr. Akash Attreya, US Health Department for his support.

Received: 28 July 2013 Accepted: 2 June 2014

Published: 13 June 2014

\section{References}

1. Krug EG, Mercy JA, Dahlberg LL, Zwi AB: The world report on violence and health. Lancet 2002, 360(9339):1083-1088.

2. Coker AL, Smith PH, MCKeown RE, King MJ: Frequency and correlates of intimate partner violence by type: Physical, sexual and psychological battering. Am J Public Health 2000, 90(4):553-559.

3. Wingood GM, DiClemente RJ, Raj A: Adverse consequences of intimate partner abuse among women in non-urban domestic violence shelters. Am J Prevent Med 2000, 19(4):270-275.

4. Tolman RM, Rosen D: Domestic Violence in the lives of women receiving welfare: Mental health, substance dependence and economic wellbeing. Violence Against Women 2001, 7(2):141-158.

5. Patel V, Kirkwood BR, Pednekar S, Pereira B, Barros P, Fernandes J, Datta J, Pai R, Weiss H, Mabey D: Gender disadvantage and reproductive health risk factors for common mental disorders in women: A community survey in India. Arch Gen Psychiatry 2006, 63(4):404-413.

6. Bates LM, Schuler SR, Islam F, Islam K: Socioeconomic factors and processes associated with domestic violence in rural Bangladesh. Int Fam Plan Perspect 2004, 30(4):190-199.

7. Jejeebhoy S, Bott S: Non consensual sexual experiences of young people: A review of the evidence from developing countries, Regional working papers, South \& East Asia, No 16: 20-21. New Delhi, India: The Population Council; 2003.

8. World Health Organization: WHO multi-country study on women's health and domestic violence against women: summary report of initial results on prevalence, health outcomes and women's responses. 2005.

9. Jain D, Sanon S, Sadowski L, Hunter W: Violence against women in India: Evidence from rural Maharashtra in India. Rural Remote Health 2004, 4(4):304.

10. Poudel GS: Domestic Violence against Women in Nepal. Gend Technol Dev 2007, 11(2):199-233.

11. García-Moreno C, Jansen HA, Ellsberg M, Heise L, Watts C: WHO multicountry study on women's health and domestic violence against women: initial results on prevalence, health outcomes and women's responses. Geneva, Switzerland: World Health Organization; 2005.

12. Karaoglu L, Celbis O, Ercan C, Ilgar M, Pehlivan E, Gunes G, Genc MF, Egri M: Physical, emotional and sexual violence during pregnancy in Malatya. Turkey Eur J Public Health 2006, 16(2):149-156.

13. Grande ED, Hickling J, Taylor A, Woollacott T: Domestic violence in South Australia: A population survey of males and females. Aust N Z J Public Health 2003, 27(5):543-550.

14. Burazeri G, Roshi E, Jewkes R, Jordan S, Bjegovic V, Laaser U: Factors associated with spousal physical violence in Albania: Cross sectional study. BMJ 2005, 331(7510):197-201.

15. Khosla AH, Dua D, Devi L, Sud SS: Domestic violence in pregnancy in North Indian women. Indian J Med Sci 2005, 59(5):195-199.

16. Tsui KL, Chan AY, So FL, Kam CW: Risk factors for injury to married women from domestic violence in Hong Kong. Hong Kong Med J 2006, 12(4):289-293.

17. Mousavi SM, Eshagian A: Wife abuse in Esfahan, Islamic Republic of Iran, 2002. East Mediterr Health J 2005, 11(5-6):860-869.

18. Abrahams N, Jewkes $R$, Laubscher R, Hoffman M: Intimate partner violence: Prevalence and risk factors for men in Cape Town. South Africa Violence Vict 2006, 21(2):247-264.

19. Gage AJ: Women's experience of intimate partner violence in Haiti. Soc Sci Med 2005, 61(2):343-364.

20. Maman S, Mbwambo JK, Hogan NM, Kilonzo GP, Campbell JC, Weiss E, Sweat MD: HIV-positive women report more lifetime partner violence: Findings from a voluntary counseling and testing clinic in Dar es Salaam. Tanzania Am J Public Health 2002, 92(8):1331-1337. 
21. Kiarie JN, Farquhar C, Richardson BA, Kabura MN, John FN, Nduati RW, John-Stewart GC: Domestic violence and prevention of mother-to-child transmission of HIV-1. AIDS 2006, 20(13):1763-1769.

22. Maziak W: Violence against women. Lancet 2002, 360(9329):343-344.

23. Hindin MJ, Adair LS: Who's at risk? Factors associated with intimate partner violence in the Philippines. Soc Sci Med 2002, 55(8):1385-1399.

24. Koenig MA, Ahmed S, Hossain MB, Khorshed Alam Mozumder AB: Women's status and domestic violence in rural Bangladesh: individual and community-level effects. Demography 2003, 40(2):269-288.

25. Xu X, Zhu F, O'Campo P, Koenig MA, Mock V, Campbell J: Prevalence of and risk factors for intimate partner violence in China. Am J Public Health 2005, 95(1):78-85.

26. Government of Nepal: The Domestic Violence and Punishment Act 2066. Kathmandu, Nepal: Government of Nepal; 2009. Accessed 12 June 2013. http:// www.lawcommission.gov.np/index.php?option=com_remository\&ltemid= 2\&func=startdown\&id=424\&lang=en.

27. Puri M, Frost M, Tamang J, Lamichhane P, Shah I: The prevalence and determinants of sexual violence against young married women by husbands in rural Nepal. BMC Res Notes 2012, 5(1):291.

28. Adair T: Men's condom use in higher-risk sex: trends and determinants in five sub-Saharan countries. 2008.

29. Mitsunaga TM, Powell AM, Heard NJ, Larsen UM: Extramarital sex among Nigerian men: polygamy and other risk factors. J Acquir Immune Defc Syndr 2005, 39(4):478-488.

30. Oyediran K, Isiugo-Abanihe UC, Feyisetan BJ, Ishola GP: Prevalence of and factors associated with extramarital sex among Nigerian men. Am J Mens Health 2010, 4(2):124-134.

31. New Era/Sacts/Family Health International: HIV/STD Prevalence and Risk Factors Among Migrant and Non-migrant Males of Acham District in FarWestern Nepal. Khatmandu, Nepal: Report to Family Health International, STD/AIDS Counseling and Training Service; 2002.

32. Anderson AF, Qingsi Z, Hua X, Jianfeng B: China's floating population and the potential for HIV transmission: A social-behavioural perspective. AIDS Care 2003, 15(2):77-185

33. Thornton A: The developmental paradigm, reading history sideways, and family change. Demography 2001, 38(4):449-465.

34. Thornton A: Reading History Sideways: The Fallacy and Enduring Impact of the Developmental Paradigm on Family Life. Chicago: University of Chicago Press: 2013.

35. Feyisetan BJ: Spousal communication and contraceptive use among the Yoruba of Nigeria. Popul Res Policy Rev 2000, 19(1):29-45.

36. Balaiah D, Naik DD, Ghule M, Tapase P: Determinants of spacing contraceptive use among couples in Mumbai: A male perspective. J Biosoc Sci 2005, 37(6):689-704

37. Kaggwa EB, Diop N, Douglas SJ: The role of individual and community normative factors: A multilevel analysis of contraceptive use among women in union in Mali. Int Fam Plan Perspect 2008, 34(2):79-88.

38. Bawah AA: Spousal communication and family planning behavior in Navrongo: A longitudinal assessment. Stud Fam Plan 2002, 33(2):185-194

39. Sharan M, Valente TW: Spousal communication and family planning adoption: Effects of a radio drama serial in Nepal. Int Fam Plan Perspect 2002, 28(1):16-25.

40. Hoelter LF, Axinn WG, Ghimire DJ: Social change, premarital nonfamily experiences, and marital dynamics. J Marriage Fam 2004, 66(5):1131-1151.

41. Axinn WG, Yabiku ST: Social change, the social organization of families, and fertility limitation. Am J Sociol 2001, 106(5):1219-1261.

42. Jewkes R: Intimate Partner Violence: Causes and Prevention. Lancet 2002, 359(9315):1423-1429.

43. Bhatta DN: Involvement of males in antenatal care, birth preparedness, exclusive breast feeding and immunizations for children in Kathmandu, Nepal. BMC Pregnancy childbirth 2013, 13(1):14

44. Kongnyuy EJ, Wiysonge CS: Alcohol use and extramarital sex among men in Cameroon. BMC Int Health Human Rights 2007, 7(1):6.

45. Koenig MA, Stephenson R, Ahmed S, Jejeebhoy SJ, Campbell J: Individual and contextual determinants of domestic violence in North India. Am J Public Health 2006, 96(1):132-138.

46. Atkins DC, Baucom DH, Jacobson NS: Understanding infidelity: Correlates in a national random sample. J Fam Psychol 2001, 15(4):735-749.

47. Alhabib S, Nur U, Jones R: Domestic violence against women: systematic review of prevalence studies. J Fam Violence 2010, 25(4):369-382.
48. Treas J, Giesen D: Sexual infidelity among married and cohabiting Americans. J Marriage Family 2000, 62(1):48-60.

49. Atkins DC, Kessel DE: Religiousness and infidelity: Attendance, but not faith and prayer, predict marital fidelity. J Marriage Family 2008 70(2):407-418

50. Islam MA: Male involvement in reproductive health in Bangladesh: A multilevel analysis. Germany: VDM Publishing House Ltd; 2008.

51. Williamson LM, Parkes $A$, Wight $D$, Petticrew $M$, Hart GJ: Limits to modern contraceptive use among young women in developing countries: a systematic review of qualitative research. Reprod Health 2009, 6(3):1-12.

52. World Health Organization: Responding to intimate partner violence and sexual violence against women: WHO clinical and policy guidelines. 2013. http://apps.who.int/iris/bitstream/10665/85240/1/9789241548595_eng.pdf Accessed May 16, 2014

doi:10.1186/1742-4755-11-44

Cite this article as: Bhatta: Shadow of domestic violence and

extramarital sex cohesive with spousal communication among males in Nepal. Reproductive Health 2014 11:44.

\section{Submit your next manuscript to BioMed Central and take full advantage of:}

- Convenient online submission

- Thorough peer review

- No space constraints or color figure charges

- Immediate publication on acceptance

- Inclusion in PubMed, CAS, Scopus and Google Scholar

- Research which is freely available for redistribution 